\title{
How Attractive are Innovation Systems for Knowledge Intensive Services' FDI? A Regional Perspective for Spain
}

\author{
Celia Torrecillas',Bruno Brandão Fischer²
}

\begin{abstract}
Following an increasing body of literature that has been generated regarding the role played by Knowledge Intensive Services in economic systems, our approach focuses on KIS international orientation (FDI) according to the attractiveness we expect Regional Innovation Systems might have in these flows. Results suggest that technological variables participate rather marginally in the process of FDI attraction. As this situation unfolds more relevantly in the case of Outward investment than Inward, we can therefore expect that Spanish investment abroad is more oriented towards asset and knowledge seeking than the inflow of investments in services and in KIS in Spanish regions.
\end{abstract}

Keywords: Spain; regional innovation systems; knowledge-intensive services; foreign direct investment.

\footnotetext{
1,2 Instituto Complutense de Estudios Internacionales, Universidad Complutense de Madrid/Grupo de Investigación en Economía y Política de la Innovación (GRINEI) Universidad Complutense de Madrid. Finca Mas Ferré, Edificio A. Campus de Somosaguas, entrada 328223 Pozuelo de Alarcón (Madrid) Tel. +00 34 913-942-490, Fax.+00 34 913-942-487 E-mail: celiatorrecillas@pdi.ucm.es, bbfischer@pdi.ucm.es
} 


\section{Introduction}

The Innovation Systems approach frames economic environments in geographically bounded territories in which firms, institutions and a whole range of agents are supposedly connected in a dynamic way that influences a given region's capacity to innovate. In this context, Foreign Direct Investment must be seen as an important agent of interaction and integration between open innovation systems. Multinational companies act not only as generators, but also as recipients of many kinds of spillovers, especially technological, and as a matter of fact efficiency and knowledge seeking can be understood - together with market seeking - as the main motives for the FDI phenomena (Dunning, 2006).

This view poses the hypothesis that there might be a complementary or competing - depending on home and host market characteristics - interest in the internationalization process, which we might define in two broad dimensions: asset seeking (comprehending knowledge and efficiency seeking strategies) and market seeking (or asset exploitation). From this theoretical perspective we have drawn the framework of this analysis: market seeking strategies have been widely analyzed - for both trade and FDI - via the well-known gravity models and other market-oriented approaches. However, this leaves us uncomfortable with the non-consideration of an asset seeking (specifically technological-knowledge seeking) motivation for the internationalization process, meaning that FDI attraction may be also be related to knowledge or technology sources. Consequently, a region with a larger mass of skilled labour, patents and R\&D would have larger inflows of investment than it would otherwise (Chung and Alcácer, 2002).

Furthermore, we aim at exploring a blurry spot in literature which deals with the approach of the internationalization of knowledge intensive services (KIS). The focus on this subsector is relevant for two main reasons: firstly, there is a growing interest and importance of this subsector in developed nations' overall economies and specifically in FDI in recent years (Kolstad and Villanger, 2008;
Ramasamy and Yeung, 2010; Bishop, 2008; Ball, Lindsay and Rose et al, 2008; den Hertog, Broersma and van Ark, 2003); and secondly, provided this situation (as well as the relative importance of service industries as a whole), we notice a lack of literature regarding internationalization activities of KIS in comparison to other sectors, such as manufactures and even services in general. Even though we acknowledge the difficulties that hinder approaches such as ours (mainly data availability issues and idiosyncrasies of services' economic behaviour), contributions must be made in order to further explore the nature of these core components of economic environments.

We believe that a model of FDI attraction based on a set of innovation systems' variables can be developed and tested, gathering complementary information on KIS' FDI flows. Furthermore, following our initial proposition, we will proceed to an analysis based on a regional context within Spain: the regional level in this case stands for the idea that it is not likely that countries perform as homogeneous unities. Therefore, in order to better comply with geographical characteristics of regions within nations, analysing Regional Innovation Systems allow a better representation of economic events and their evolution.

Therefore, our analysis takes place using three core Innovation Systems' variables (Gross Expenditure in R\&D, Researchers per million people and a Patent Index) in order to assess their influence on KIS FDI (inward and outward flows) in Spanish regions. To develop this analysis we address their investment relationship with foreign Innovation Systems at their national level'.

We believe that such an analysis contributes to knowledge in terms of FDI drivers in KIS, hence highlighting a side of innovation systems usually ignored, which is its capacity of influencing on international investment flows. Results shall be useful for regional policymakers in terms of evaluating their strategies of KIS' FDI attraction in structural terms, thus setting a framework for sustainable positioning over time, instead of resorting to the usual suspect: tax benefits ${ }^{2}$.

\footnotetext{
' Meaning, for example, that we will assess the flow of FDI of a given Spanish region, say Madrid, with a country-level agent, say Germany. ${ }^{2}$ We are aware of tax policy influence in attraction FDI at national and regional levels. Nonetheless, it is not our goal here to assess its impacts in these flows.
} 
Thus, this article is developed according to the following structure: chapter 2 develops on the literature regarding services internationalization and the specific role of KIS. Chapter 3 brings some general aspects of Regional Innovation Systems. Chapter 4 develops on the methodological approach of this article, setting the foundations for the technological determinants of our FDI approach. Chapter 5 offers empirical results and chapter 6 concludes with some policy implications.

\section{Internationalization of services and the role of KIS}

The services sector is an active generator of productivity improvements in many developed nations (Metcalfe and Potts, 2007), affecting also international economic relations, and thus becoming a topic of interest in the field of international trade and investment (Jenícek, 2007). A plausible hypothesis to explain the growth of services points to the externalization of business activities (Guerrieri and Meliciani, 2005) due to a process of industrial concentration in companies' core businesses (Koch and Strotmann, 2005). For the case of KIS, its main contribution to economic environments refers to its capacity of generating innovative dynamics not only on its own context, but also across sectors through knowledge production, diffusion, supply and absorption ${ }^{3}$ (Muller and Zenker, 200I; Czarnitzki and Spielkamp, 2003; Musolesi and Huiban, 2010). Empirical results show that the presence of KIS in a given region positively affects the innovative capacity of companies in general (García-Quevedo and Mas-Verdú, 2008; Camacho and Rodríguez, 2005).

Along with this comes a fast internationalization process: FDI in services has increased considerably in recent years. However, literature has not followed this trend and it is still largely focused on manufacturing companies. We find it mandatory to move to the internationalization analysis of such sectors because of both their international orientation and impact on economy as a whole. Focusing on KIS, for example, literature tells us that they have - in comparison to other sectors of the economy - a higher propensity to internationalize their activities (Javalgi et al, 20Il; Chen, 2006) and we can also notice that internationalization activities in services - inward and outward foreign direct investment, imports and exports - have significant impacts on firms' innovative capabilities (Blind and Jungmittag, 2004).

Focusing on FDI is a suitable strategy to approach the case of services. Because of the 'non-tradability of services' output' principle, which highlights the costs of trade in services and its intangible character, there is usually a need for direct interaction between supplier and consumer, making physical presence in a given market a must for these activities, especially when they are personalized and operate in an environment of high uncertainty and risk $^{4}$ (Guerrieri and Meliciani, 2005; De Bruijn, Kox and Arjan, 2008; Aslesen and Isaksen, 2007; Tether and Hipp, 2002). This situation highlights the need for KIS firms to establish presence in foreign markets regarding their internationalization processes, thus allowing a close proximity with their markets and facilitating the interaction with customers (Ball, Lindsay and Rose, 2008; García-Quevedo and Mas-Verdú, 2008).

Furthermore, while traditional theory for the internationalization of manufacturing firms tells us that the location advantages of FDI are usually related to cost factors, in the case of KIS the labour force must still be highly skilled (in direct comparison with manufacturing production personnel), thus implying that wages may not always provide KIS firms with advantages when setting their business abroad (Camacho and Rodríguez, 2005). Hence, the internationalization process of KIS must also take into account the industrial environment and economic conditions of host markets in terms of the specific areas of activity of KIS companies (Javalgi et al, 20II), i.e., FDI in KIS have by definition an asset seeking orientation (apart from market seeking).

These location and physical proximity issues drive us to the role that geography plays in the activities of KIS. Since we are resorting to a regional context of innovation systems in Spain, now we move to some general aspects related to this geographical level of analysis before stating the methodological approach built to deal with our research target.

\footnotetext{
${ }^{3}$ See Appendix I for a list of KIS subsectors used in this research.

${ }^{4}$ Also, due to methodological issues in accountancy, services are often misrepresented via trade data.
} 


\section{The Regional Perspective of Innovation Systems}

The concept of RIS is mainly developed on a framework comprising different theories and approaches on institutions, systems and evolutionary economics where new regionalist literature and the idea of territorial innovation models highlight the importance of localized innovative activities in generating agglomeration - the intention is to assess the knowledge generation of the specific processes and their influences within a given regional economic system (Uyarra, 2007; 2010; Terlouw, $200 \mathrm{I})$. RIS are justified by the belief that the regional scale of analysis is fundamental to understand the dynamics of agents' innovative behaviour given that it is at the regional level that economic interactions leading to innovative capabilities and performance occur, even in a globalized scenario (Scott, 2006; Vellinga, 2000).

Furthermore, this level of geographical analysis finds support in that future economic systems will be further focused on knowledge intensive activities and highly unbalanced in space (Nuur, Gustavsson and Laestadius, 2009). Outcomes of RIS research aggregated fundamental knowledge to better understand the role of physical, cognitive and institutional proximity as well as the local economic context in determining innovative capabilities of agents (Trippl, 2010; Sternberg, 2007).

It is of interest to offer this chapter with a clear justification of the motives that drove us to undertake a regional level approach instead of using the national unit. We are quite aware that dealing with FDI flows in this case might be equivalent to address some regional results as if they represented the whole geographical area when in truth they gather information for a small set of influential agents ${ }^{5}$. Notwithstanding, the regional perspective of internationalization allows us to cope with a better sense of reality instead of achieving more elegant econometric models.
Examples to support this idea are vast in literature. In the first place, we must consider that national innovation and technological policies have been increasingly supplemented by initiatives at the regional level in a process usually known as "devolution" which poses potential issues of diversity and conflict between locations within a country, especially because innovation policy downscaled to the regional level might not cope with structural problems related to innovation itself and globalization (Kuhlmann and Edler, 2003; Howells, 2005; Nuur, Gustavsson and Laestadius, 2009) ${ }^{6}$.

What to expect, then if not a diversity of profiles within National Innovation Systems? The concept of region comprises aspects related to geography, functionality, economy, institutions and culture, i.e., the regional approach reduces not only policy related heterogeneity within nations, but also a wide array of economic and social aspects which are usually disregarded (Uyarra, 2007).

What we find is that a subnational focus of the National Innovation System concept might reduce problems of scale and complexity of analysis (Cooke, Uranga and Etxebarria, 1997) ${ }^{7}$. However, we must notice that taking Regional Innovation Systems as granted can be tricky for the analyst: Cooke (200I) suggests that regions do not necessarily represent Regional Innovation Systems, as this is actually a rare event. Taking that into account, what our research approximates as innovation systems' variables are, as a matter of fact, fairly comparable indicators of the innovative environment, providing us with confidence when analyzing regions in Spain.

This approach is especially suitable for the Spanish case once it is noticed that this country is divided in 17 autonomous and fairly heterogeneous (economically, culturally, in terms of size and natural endowments) regions with a relatively high level of independence in economic policymaking. De la Fuente (2002) even concluded that differences in the capacity of these regions to converge economically

\footnotetext{
${ }^{5}$ In this regard we find that firm-specific drivers of innovation matter more for their innovative performance than the geographical (regional or national) context in which they are embedded (Beugelsdijk, 2007; Sternberg and Arndt, 200 I). For practical (data availability) and methodological (our goal is to assess regions as aggregated agents in order to provide policy recommendations) reasons we do not go any deeper in this direction.

${ }^{6}$ Contradicting this view, we have the idea of regional independence in terms of structural and economic policy not giving a realistic idea of the context since usually the national government plays a major role in defining regional policies (Uyarra and Flanagan, 20I0).

${ }^{7}$ We also are addressing a gap mentioned by Sternberg (2007) regarding the usual focus of RIS analyses being on intraregional dynamics, thus not approaching external interactions.
} 
can be explained by idiosyncratic factors that are hard to identify, let alone measure. A concrete example of this diversity is found in Durán and Ubeda (2005) who using the Investment Development Path approach, classified Spain as a developed country (level 4), but these results were only a representation of the cases of Madrid and Catalonia since the remaining regions were not on the same stage. Besides, the innovative tradition of these regions generates distinct $R \& D$ expenditure levels, relative number of researchers or distance to the technological frontier (Vence-Deza and González-López, 2005).

On the other hand, our proposition is exploratory, as usually happens in cases like these: Systems of innovation approaches do not offer a proper theory with clearly defined causal relationships between variables, but they provide an interesting conceptual framework for empirical developments (Uyarra and Flanagan, 2010). Based on that, our expectations are that RIS - as we model - affect FDI flows in KIS due to what they potentially offer to firms embedding their activities in them - which situate our whole approach under the umbrella of asset seeking internationalization strategies.

\section{Data and Methodology}

The conceptual scenario drawn from the literature review poses some challenges for the comprehension of international flows in KIS. Our goal in this study is to assess the importance that technological factors play in this location decision: to what extent does the need to acquire technology, to have access to skilled labor and to a pool of established knowledge, influence the orientation of FDI in Knowledge-Intensive Services (KIS)?

Data used in our estimations come from the sources described in table I.

\begin{tabular}{|c|c|c|c|c|}
\hline VARIABLES & & DESCRIPTION & PERIOD & SOURCE \\
\hline LnIFDI & $\begin{array}{l}\text { LnIFDI in Services } \\
\text { LnIFDI in KIS }\end{array}$ & $\begin{array}{l}\text { FDI inward and in million } \\
\text { Euros for each region in } \\
\text { Spain }\end{array}$ & $\begin{array}{l}\text { M ean for the period } \\
\text { 2003-2008 }\end{array}$ & DATAINVEX \\
\hline LnOFDI & $\begin{array}{l}\text { LnOFDI in Services } \\
\text { LnOFDI in KIS }\end{array}$ & $\begin{array}{c}\text { FDI Outward and in million } \\
\text { Euros for each region in } \\
\text { Spain }\end{array}$ & $\begin{array}{l}\text { M ean for the period } \\
\text { 2003-2008 }\end{array}$ & DATAINVEX \\
\hline LnGDP*GERD & & $\begin{array}{c}\text { GDP multiplied by the } \\
\text { Gross expenditures in } R \& D\end{array}$ & $\begin{array}{l}\text { M ean for the period 2003- } \\
2008\end{array}$ & WDI/OECD Stat \\
\hline LnHR & & $\begin{array}{l}\text { Researchers in R\&D per } \\
\text { million of people }\end{array}$ & $\begin{array}{l}\text { M ean for the period 2003- } \\
2007\end{array}$ & OECD/Eurostat \\
\hline LnTECHDIST & & $\begin{array}{l}\text { Difference between pair of } \\
\text { countriesÕpatent index }{ }^{8}\end{array}$ & $\begin{array}{c}\text { M ean of patents and } \\
\text { population for the period } \\
2003-2008\end{array}$ & WDI/OECD Stat \\
\hline LnFDI M anufacturing & $\begin{array}{l}\text { LnOFDI in } \\
\text { Manufacturing }\end{array}$ & $\begin{array}{l}\text { FDI inward and in million } \\
\text { Euros for each region in } \\
\text { Spain }\end{array}$ & $\begin{array}{l}\text { M ean for the period } \\
2003-2008\end{array}$ & DATAINVEX \\
\hline
\end{tabular}

Table I. Variables of analysis, sources and descriptions.

ISSN: 07I8-2724. (http://www.jotmi.org)

Journal of Technology Management \& Innovation ( Universidad Alberto Hurtado, Facultad de Economía y Negocios 
We have proceeded to a cross-section analysis, using natural logarithms of the original data. All models used mean values for the period 2003-2008, which allowed us to gather a larger number of observations and reduce the effects of FDI instability over time, thus creating a more robust picture of the situation. The number of countries used for FDI flows' analysis sums up to 42 . We gathered data for all of the 17 Spanish regions.

One may argue that our explanatory variables are oriented towards a "hard" technological side of innovation systems, which would not be adequate for exploring relationships with FDI flows in the services sector. Nonetheless, we find in literature (Sirilli and Evangelista, 1998) that the innovative behaviour of services is usually similar to that found in manufacturing companies and also that the relevance of technological achievements is already of utmost importance for services. This idea suggests that for as limited as our approach may be (especially in gathering the complexity of innovation systems through a narrow set of variables) it still allows us to deepen the knowledge in the area we are studying.

For robustness sake we also included the analysis of the service industry as a whole in our estimations. Since it is not our goal to compare KIS with "traditional" services we did not proceed to a subsectoral decomposition in this regard. This would reduce the degree of freedom of our models while drifting the analysis away from our propositions. Thus, results for the service industry should be understood as a benchmark for the KIS approach.

A special justification is needed for the use of patents as a component of analysis in the case of services, i.e., TechDist. The index we built is based on the United Nation's TAI - Technology Achievement Index (UNDP, 200I). The use of patents as a proxy of technological distance between nations was also used by the ArCo Index (Archibugi and Coco, 2004) and by Fu and Yang (2007), among others.

Nonetheless, we structured data in a way to measure not technological distance per se, but technological heterogeneity. Since we are dealing with natural logarithms of the original observations we had to transform these in order to have only positive "distances". Therefore, if a given country/region $A$ lags behind country/region $B$ in say .100 (patent index) and country $C$ lags .100 (patent index) behind country $A$, we can say that $B$ and $C$ are equivalently heterogeneous regarding country $A$.

The use of a "technological heterogeneity" indicator between countries gives us an approximation of Innovation Systems and technological capabilities. Furthermore, the use of this variable relies on the strong relationship between FDI in Manufacturing and in Services ${ }^{10}$, suggesting that if patents can be used for the former, it should not provide distorted results for the latter. Also, since the focus of this paper lies on KIS, it must be pointed out that this specific subsector is strongly related to productive services, meaning that our analysis will be dealing mainly with services that seek industrialized areas to perform their activity. Also, as we have stressed previously, technological features already occupy a strategic position for services and this trend is likely to increase. Nonetheless, we recognize the limitation of this indicator, but insist that it can be useful given the lack of equivalent output measures for innovation in services.

Also, the use of researchers per million people might be criticized and the use of other variables of education levels can be considered as more suitable for the case of services. Nonetheless, not only KIS are expected to couple with knowledge intensive manufactures (which absorb a fair deal of researchers in private sector) but KIS themselves can be intensive in highly skilled workforce. Thus, we believe that there is no reason to consider other education variables as necessarily more adequate for our approach. Furthermore, there is no reason to expect that there are relevant discrepancies in levels of higher education attainment rates in a region/country and its level of researchers within the population.

Aiming at analyzing the impact technological variables might have in Outward and Inward services/KIS's FDI for the case of Spanish regions, we developed some regressive

\footnotetext{
${ }^{8}$ The LnTECHDIST was built by the Patent index. The methodology has been used is the TAl based on the following formula: (Observed value - Minimum observed)/(Maximum observed - Minimum observed)

${ }^{9}$ Table I shows that these "distances" or measures of heterogeneity are calculated as a difference between the patent index from host and home economies in the FDI relationship.

${ }^{10} \mathrm{We}$ also develop models with FDI flows in manufactures, given the findings of Ramasamy and Yeung (2010), Defever (2006), Kimura and Lee (2006) and Ramasamy and Yeung (2010) which suggest that FDI in services follow FDI in manufactures.
} 
models. Our goal is to obtain results that guide us in providing information regarding: a) how do Innovation Systems influence in the attraction of FDI by Spanish regions; and b) to what extent the technological variables of foreign host countries influence in the investment decision (KIS/services) of Spanish regions.

We also have made a distinction between the data for KIS and the aggregated data for services (including all of its subsectors). Given the expected heterogeneity among these subsectors, we believe it can be useful to use the services sector as a whole in other to provide some benchmark material when analyzing the econometric results.

In the models we have included also variables to control the effects of origin and destination of investment - if whether they come from EU-27 countries or not - and to control for the level of development of Spanish regions (for this we have considered Madrid, Catalonia and the Basque Country as developed regions and the remaining fourteen regions as "developing"). The use of the Dummy EU-27 is justified by the fact that FDI flows within the region are facilitated by smaller influences of regulations and restrictions.

Regressions sum to a total of four equations: 2 for Inward FDI and 2 for Outward FDI. The second model in both cases include the presence of the FDI in manufacturing as an explanatory variable in order to verify if they can be related to these FDI Inward and Outward flows.

The models can be described as follows:

\section{(Model I)}

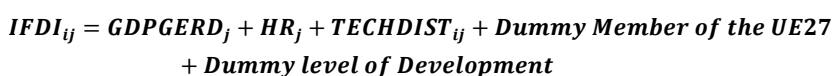

Where: IFDlij: refers to Inward FDI between country "i" to country"j"; GDPGERDj: is the GDP of country "j" by its Gross Expenditures in R\&D as a percentage of the GDP; HRj: is a measure of highly qualified workforce of country " $j$ " measured by researchers in R\&D per million people; TECHDISTij: refers to a measure of technological heterogeneity between nations/regions measured by the absolute (no negative values) of countries/regions' patent index gathered from PCT patent applications.

Dummy Member of the UE 27; A measure of the influence of the UE as destination of origin in the FDI.

Dummy level of development; as a measure of the level of development between Spanish regions.

\section{(Model 2)}

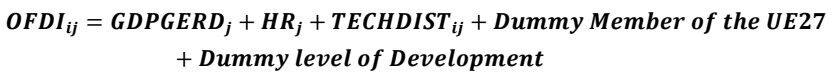

Where;

OFDIij; refers to Outward FDI between country "i" to country "j”. GDPGERDj; HRj; TECHDISTij; and Dummies idem above.

\section{(Model 3)}

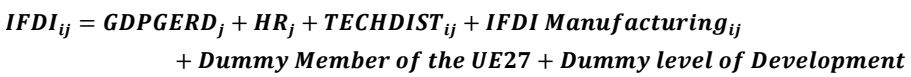

Where;

IFDI Manufacturing ij: refers to the Inward FDI in Manufacturing between the region " $\mathrm{j}$ " to the country "i". IFDIij; GDPGERDj; HRj;TECHDISTij; and Dummies idem above.

\section{(Model 4)}

OFDI $_{i j}=$ GDPGERD $_{j}+H R_{j}+$ TECHDIST $_{i j}+$ OFDI Manufacturing ${ }_{i j}$ + Dummy Member of the UE27+Dummy level of Development

Where;

OFDI Manufacturing: refers to Outward FDI in Manufacturing between the country "i" to the region "j". IFDIij; GDPGERDj; HRj; TECHDISTij; and Dummies idem above. 


\section{Results}

Results for Inward FDI (IFDI) in KIS and in services (investment inflows in the distinct Spanish regions) are presented in table 2. We had to proceed to a two-stage approach in order to comply with multicollinearity between the variables LnGDPGERD and LnHR.

Results do not indicate a strong influence of technology related variables in the attraction of FDI in Spain - which can be gathered from the variables' coefficients and models' R2. It should also be noticed that we have a better fit for the models comprising services instead of those only for KIS. This is interesting, since we would expect that KIS would seek more developed Innovation Systems than services in general which does not happen in this case - taking into account our limited proxy variables for these systems. In a more general picture of this case, Spain does not seem to attract FDI in services/ KIS at least directly because of the Regional Innovation Systems - one might think, though, that these influence in the general economic framework, which might indeed be more significant in this case.

\begin{tabular}{|c|c|c|c|c|c|}
\hline & Services (1) & KIS (1) & & Services(1) & KIS (1) \\
\hline LnGDPGERD & $(-) .019$ & .029 & In $H R$ & $(-) .016$ & .047 \\
\hline \multirow[t]{2}{*}{ Ln TechDist } & $.260^{* * *}$ & $.203^{* * *}$ & In TechDist & $.260^{* * *}$ & $.203^{* * *}$ \\
\hline & $(.000)$ & $(.000)$ & & $(.000)$ & $(.000)$ \\
\hline \multirow[t]{2}{*}{ Dummy Level of Development } & $.368 * * *$ & $.227^{* *}$ & Dummy Level of Development & $3.64^{* * *}$ & $2.16^{* *}$ \\
\hline & $(.000)$ & $(.032)$ & & $(.000)$ & $(0.14)$ \\
\hline \multirow[t]{2}{*}{ Dummy EU } & $.170^{* * *}$ & $.218^{* * *}$ & Dummy EU & $.170^{* * * *}$ & $.216^{* * *}$ \\
\hline & $(.000)$ & $(.000)$ & & $(.000)$ & $(.000)$ \\
\hline Rsq & .232 & .138 & Rsq & .232 & .138 \\
\hline$N$ & 426 & 275 & $N$ & 426 & 275 \\
\hline$* * *$ Sig $1 \%$ & & & $* * * \operatorname{Sig} 1 \%$ & & \\
\hline **Sig 5\% & & & $* *$ Sig $5 \%$ & & \\
\hline${ }^{*}$ Sig $10 \%$ & & & *Sig $10 \%$ & & \\
\hline
\end{tabular}

Table2: Results for Inward FDI/ Note: Standard errors in parentheses

We also verified a positive heterogeneity in TechDist, meaning that incoming investments in Spanish regions are usually related to home countries that are in different technological stages than regions where they invest. This might indicate the presence of a cost-focused offshoring process, which would explain the low significance of the other IS variables - we find support for that in the significant and positive effect of the Dummy EU, which represents partners from within the European Union". Nonetheless, we must notice that services are more oriented towards more developed regions in Spain than KIS, which can be regarded as a surprising result.

\footnotetext{
"This conclusion comes from the laggard position of the Spanish Innovation System as a whole in the context of the European Union. Descriptive statistics confirm this hypothesis, since IFDI in Spanish regions mainly come from Germany, France and the Netherlands.
} 
Moving to the outflow of investments from Spanish regions (table 2) we do not have a significant better fit for our models as per the analysis of the R2 coefficient. Again, Services couple better with our explanatory variables than KIS do. Nonetheless, it is interesting noticing that GDPGERD and HR (as technological variables) seem to play an important role in the attraction of FDI in KIS from Spanish regions, while TechDist, contributes little to the model, suggesting that the technological heterogeneity is not a relevant determinant on where Spanish firms decide to invest. Nonetheless, HR has a negative signal, suggesting that countries with lower rates of researchers per million inhabitants are more attractive for internationalizing Spanish firms. Also, we can see that, as expected, more developed regions invest more abroad, but Spain does not seem to be oriented towards the European Union in this regard.

\begin{tabular}{|lll|}
\hline & Services(2) & KIS(2) \\
\hline Ln GDPGERD & $.783^{* * *}$ & $.761^{* * *}$ \\
Ln HR & $(.000)$ & $(.000)$ \\
& $(-) .580^{* * *}$ & $(-) .532^{* *}$ \\
Ln Tech Distance & $(.000)$ & $(.004)$ \\
& $(-) .087$ & $(-) .167^{*}$ \\
Dummy level of Develpment & & $(.094)$ \\
& $.429 * * *$ & $.345^{* * *}$ \\
Dummy EU member & $(.000)$ & $(.000)$ \\
& .032 & .108 \\
Rsq & & .160 \\
$N$ & .250 & 179 \\
\hline *** Sig 1\% & 347 & \\
**Sig 5\% & & \\
*Sig 10\% & & \\
& & \\
\hline
\end{tabular}

Table 3: Results for Outward FDI / Note: Standard errors in parentheses

When adding FDI in manufacturing to our analysis, this seems to be a significant determinant of investment in the Spanish regions - more strongly for KIS than for services in general, which might indicate how these KIS couple with industrial firms, since many of its subsectors correspond directly to business services.
The coefficients of the other variables change, as well as their significance in some cases when we include this control variable. For example, GDPGERD and HR become significant for services (but not for KIS). It is interesting to notice that for both, signals are negative. Thus, there is a contraposition between them and FDI in manufacturing. Again, these results indicate that the influence of Innovation Systems is rather low in direct terms to the attraction of FDI. 


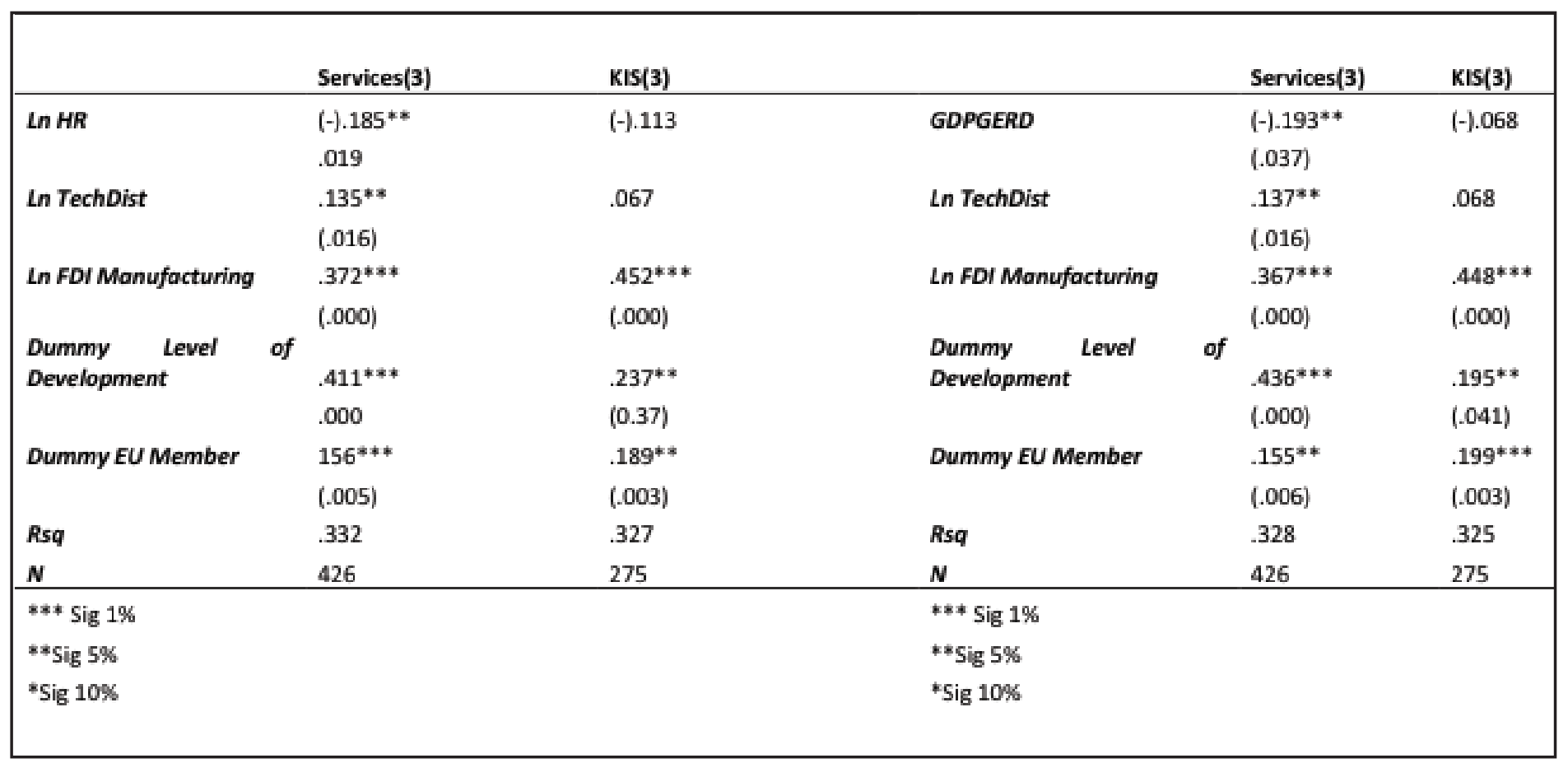

Table 4: Results for Inward FDI with manufacturing/ Note: Standard errors in parentheses

In the analysis of Outward FDI in KIS and services, FDI in manufacturing does not seem to play a determinant role at all, even though this variable has a significant coefficient for services (not for KIS) - but its coefficient is rather small. Other variables remain in similar situations to those we showed previously in the model without investment in manufactures. However, TechDist now appears as significant (especially for KIS) and providing some contribution to the explanatory power of the models with a negative sign, suggesting that considering the variables included in the model, Spanish regions invest more in those countries that are in a technological situation more homogeneous in comparison to their own.

\begin{tabular}{|lll|}
\hline & Services(4) & KIS(4) \\
\hline Ln GDPGERD & $.606^{* * *}$ & $.735^{* * *}$ \\
Ln HR & $(.000)$ & $(.002)$ \\
& $(-) .344^{* *}$ & $(-) .313$ \\
Ln Tech Distance & $(0.28)$ & $(-) 2.97^{* * *}$ \\
& $(-) .138^{*}$ & $(.009)$ \\
Ln FDI Manufacturing & $(0.78)$ & $(-) .016$ \\
& $.172^{* *}$ & $.449 * * *$ \\
Dummy level of Develpment & $(.012)$ & $(.000)$ \\
Dummy EU member & $.410^{* * *}$ & .011 \\
Rsq & $(.000)$ & .257 \\
N & .001 & 179 \\
\hline *** Sig 1\% & .312 & \\
**Sig 5\% & 347 & \\
*Sig 10\% & & \\
\hline
\end{tabular}

Table 5: Results for Outward FDI with manufacturing/ Note: Standard errors in parentheses 


\section{Final Remarks and Policy Implications}

Extensive research shows us that it cannot be denied that the development of a strong innovative environment acts in favor of a given region's development and growth. In this sense, our analysis in this article aimed at approaching the influence of some technological constructs in the process of regional internationalization of Spanish regions via FDI for the specific case of knowledge-intensive services. As Uyarra (2007, p. 256) puts it, 'regional decision-making needs to be supported with better intelligence in terms of qualitative and quantitative indicators and a better grasp of context-specific regional trajectories'. Also, we agree that emphasis in innovation and technology policies in Spain should shift towards a more services oriented rationale (Camacho and Rodríguez, 2005).

Results suggest that technological variables participate in the process of FDI attraction but marginally. As this situation unfolds more relevantly in the case of Outward investment than Inward, we can therefore expect that Spanish investment abroad is more oriented towards asset and knowledge seeking than the inflow of investments in KIS in Spanish regions - which appear to seek costefficient operations and to follow FDI in manufactures.

Nonetheless, there are some limitations to the appropriation of our results that must be considered. Further tests with composite indicators that better represent the many dimensions of a Regional and National Innovation Systems must be taken into account. Also, better proxies for the case of technological heterogeneity in services must be found, since our approach deals only with patents and it is known that this does not necessarily represent the innovative capacity of KIS.

In any case, our expectations and suggestions for future empirical developments is to consider Innovation Systems (Regional or National) as engines of economic growth which would affect indirectly the attraction of FDI by fostering stronger markets which could be more profitable for companies. To be cost competitive might be an interesting strategy to attract FDI in the short term, but in the longer run, developing strong economic systems should be a primary goal in order to be sustainably competitive and achieve a higher level of social welfare, especially when one considers that services have a tendency of being less price-elastic than manufactures (Barcenilla-Visús, 2005).
It is also worth thinking about the possibility of a feedback loop regarding the presence of asset and knowledgeseeking FDI: if firms locate operations in geographical areas that have more developed Innovation Systems, hence contributing positively to this system, they will foster the attraction of new FDI and so on. Following this logic, any variable that attracts FDI and that is also influenced by it may configure a virtuous circle of investment. A very similar conclusion to this one can be drawn from the propositional discourse of Uyarra and Flanagan (2010).

In terms of policymaking and the central role KIS play in economic systems nowadays, it should be mentioned the attractiveness of developing a competitive structure of manufacturing MNEs in order to establish a region as receptor hub of KIS investments. Our results (as well as empirical evidence of other authors mentioned in this article) suggest a strong relationship between these two activities.

\section{Acknowledgments}

We are thankful to comments and suggestions provided by Prof. Javier Revilla-Diez, Prof. Silvia Massini, Prof. Isabel Alvarez and Prof. Phillipe Laredo.

\section{References}

ARCHIBUGI, D., Coco, A. (2004). A new indicator of technological capabilities for developed and developing countries (ArCo). World Development, 32(4), 629-654.

ASLESEN, H., Isaksen, A. (2007). Knowledge Intensive Business Services and Urban Industrial Development. The Service Industries Journal, 27(3), 321-338.

BALL, D., Lindsay, V., Rose, E. (2008). Rethinking the paradigm of service internationalisation: less resourceintensive market entry modes for information-intensive soft services. Management International Review, 28(4), 4I3-43I.

BARCENILLA-VISÚS, S. (2005). Exportaciones de servicios: evidencia empírica para los países de la Unión Europea. Información Comercial Española, (824), pp. 39-48. 
BEUGELSDIJK, S. (2007). The regional environment and a firm's innovative performance: a plea for a multilevel interactionist approach. Economic Geography, 83(2), 181-199.

BISHOP, P. (2008). Spatial spillovers and the growth of knowledge intensive services. Tijdschrift voor Economische en Sociale Geografie, 99(3), 28I-292.

BLIND, K., Jungmittag, A. (2004). Foreign direct investment, imports and innovations in the service industry. Review of Industrial Organization, 25(2), 205227.

CAMACHO, J.A., Rodriguez, M. (2005). How innovative are services? An empirical analysis for Spain. The Service Industries Journal, 25(2), 253-27I.

CHEN, Y. (2006). Incomplete Global Integration and Regional Knowledge-Intensive Service Industries. The Service Industries Journal, 26(2), 223-248.

CHUNG, W., Alcácer, J. (2002). Knowledge Seeking and Location Choice of Foreign Direct Investment in the United States. Management Science, 48(I2), I534-I554.

COOKE, P. (200I). Regional innovation systems, clusters, and the knowledge economy. Industrial and Corporate Change, 10(4), 945-974.

COOKE, P., Uranga, M.G., Etxebarria, G. (1997). Regional innovation systems: institutional and organizational dimensions. Research Policy, 26(4-5), 475-49I.

CZARNITZKI, D., Spielkamp, A. (2003). Business services in Germany: bridges for Innovation. The Service Industries Journal, 23(2), I-30.

DE BRUIJN, R., Kox, H., Lejour, A. (2008). Economic benefits of an Integrated European Market for Services. Journal of Policy Modeling, 30(2), 30I-319.

DEFEVER, D. (2006). Functional fragmentation and the location of multinational firms in Europe. Regional Science and Urban Economics, 36(5), 658-77.

DEN HERTOG, P., Broersma, L., van Ark, B. (2003). On the Soft Side of Innovation: Services Innovation and its Policy Implications. De Economist, I5I(4), 433-452.
DUNNING, J.H. (2006). Towards a paradigm of development: implications for the determinants of international business activity. Transnational Corporations, I5(I), 173-227.

DURÁN, J., Úbeda, F. (2005). The investment development path of newly developed countries. International Journal of Economics of Business, 12(I), 123-327.

DELAFUENTE, A. (2002). On the Sources of Convergence: A Close look at the Spanish Regions. European Economic Review, 46(3), pp. 569-599.

FU, X., Yang, Q. (2007). Exploring the cross-country gap in patenting: A stochastic Frontier Approach. Research Policy, 38(7), 1203-1213.

GARCÍA-QUEVEDO, J., Mas-Verdú, F. (2008). Does only size matter in the use of knowledge intensive services? Small Business Economics, 3I(2), pp. I37-I46.

GUERRIERI, P., Meliciani, V. (2005). Technology and International competitiveness: the interdependence between manufacturing and producer services. Structural Change and Economic Dynamics, 16(4), 489-502.

HOWELLS, J. (2005). Innovation and regional economic development: a matter of perspective? Research Policy, 34(8), $1220-1234$.

JAVALGI, R., Gross, A., Joseph, W., Granot, E. (20II). Assessing competitive advantage of emerging markets in knowledge intensive business services. Journal of Business and Industrial Marketing, 26(3), I7I-I80.

JENÍCEK, V. (2007). World trade with services in globalisation processes. Agricultural Economics, 53(2), 55-64.

KIMURA, F., Lee, H. (2006). The Gravity Equation in International Trade in Services. Review of World Economics, 142(I), 92-12I.

$\mathrm{KOCH}, \mathrm{A}$., Strotmann, H. (2005). The Impact of Functional Integration and Spatial Proximity on the Post-entry Performance of Knowledge Intensive Business Service Firms. IAW Discussion Paper n. 18. http://www.iaw.edu/ RePEc/iaw/pdf/iaw_dp_18.pdf [Accessed March 17, 20II]. 
KOLSTAD, I., Villanger, E. (2008). Determinants of foreign direct investment in services. European Journal of Political Economy, 24(2), 518-533.

KUHLMANN, S., Edler, J. (2003). Scenarios of technology and innovation policies in Europe: investigating future governance. Technological Forecasting \& Social Change, 70(7), 619-637.

METCALFE, J. S., Potts, J. (2007). Internationalization of services: the evolutionary perspective. Manchester Business School Working Paper n. 53I. http://www.mbs. ac.uk/cgi/apps/research/working-papers/view/?wld=138. [Accessed February 4, 20II].

MULLER, E., Zenker, A. (200I). Business services as actors of knowledge transformation: the role of KIS in regional and national innovation systems. Research Policy, $30(9), 1501-1516$.

MUSOLESI, A., Huiban, J.P. (2010). Innovation and productivity in knowledge intensive business services. Journal of. Productivity Analysis, 34(I), 63-8I.

NUUR, C., Gustavsson, L., Laestadius, S. (2009). Promoting regional innovation systems in a global context. Industry and Innovation, 16(I), 123-139.

RAMASAMY, B., Yeung, M. (2010). The Determinants of Foreign Direct Investment in Services. The World Economy, 33(4), 573-596.

SCOTT, A. (2006). Entrepreneurship, innovation and industrial development: geography and the creative field revisited. Small Business Economics, 26(I), I-24.

SIRILLI, G., Evangelista, R. (1998). Technological innovation in services and manufacturing: results from Italian surveys. Research Policy, 27(9), 88I-899.

STERNBERG, R. (2007). Entrepreneurship, proximity, and regional innovation systems. Tijdschrift voor Economische en Sociale Geografie, 98(5), 652-666.

STERNBERG, R., Arndt, O. (200I). The firm or the region: what determines the innovation behavior of European firms? Economic Geography, 77(4), 364-382.
KANÓ, I., Vas, Z. (2010). Do knowledge enterprises flock together? Evidence from Hungary at sub-regional level. Regional Studies Association Annual International Conference 2010. May 24th - 26th, Pécs. http://regionalstudies-assoc.ac.uk/events/2010/may-pecs/papers/ Izabella.pdf. [Accessed December II, 20I0].

TERLOUW, K. (200I). Regions in geography and the regional geography of semiperipheral development. Tijdschrift voor Economische en Sociale Geografie, 92(I), 76-87.

TETHER, B., Hipp, C. (2002). Knowledge Intensive, Technical and Other Services: Patterns of Competitiveness and Innovation Compared. Technology Analysis and Strategic Management, I4(2), I63-182.

TRIPPL, M. (2010). Developing cross-border regional innovation systems: key factors and challenges. Tijdschrift voor Economische en Sociale Geografie, I0I(2), I50-160.

UYARRA, E. (2007). Key dilemmas of regional innovation policies. Innovation: The European Journal of Social Science Research, 20(3), 243-26I.

UYARRA, E. (2010). What is evolutionary about regional systems of innovation? Implications for regional policy. Journal of Evolutionary Economics, 20(I), pp. II5-137.

UYARRA, E., Flanagan, K. (2010). From regional systems of innovations to regions as innovation policy spaces. Environment and Planning C: Government and Policy, 28(4), 68I-695.

VELLINGA, M. (2000). Economic internationalisation and regional response: the case of north eastern Mexico. Tijdschrift voor Economische en Sociale Geografie, 91(3), 293-307.

VENCE-DEZA, X., González-López, M. (2005). Los servicios intensivos en conocimiento, especialización y crecimiento en Europa. Información Comercial Española, (824), pp. 117-137 


\section{APPENDIX I- KIS Subsectors}

2 digit NACE Rev. 2 (Based on Kanó and Vas, 2010).

50 Water transport

5I Air transport

59 Motion picture, video and television programme production, sound recording and music publishing activities

60 Programming and broadcasting activities

6I Telecommunications

62 Computer programming, consultancy and related activities

63 Information service activities

64 Financial service activities, except insurance and pension funding

65 Insurance, reinsurance and pension funding, except compulsory social security

66 Activities auxiliary to financial services and insurance activities

69 Legal and accounting activities

70 Activities of head offices; management consultancy activities

7I Architectural and engineering activities; technical testing and analysis

72 Scientific research and development

73 Advertising and market research

74 Other professional, scientific and technical activities

78 Employment activities

80 Security and investigation activities 
J. Technol. Manag. Innov. 20II,Volume 6, Issue 4 